\title{
DYNAMIC SIMULATION AND RANKING OF USING RESIDENTIAL-SCALE SOLAR WATER HEATER IN IRAN
}

\author{
Shahram REZAPOUR ${ }^{1}$, Mehdi JAHANGIRI ${ }^{2}$, Arezoo Ghadiri SHAHREZAIE ${ }^{3}$, \\ Alireza GOLI ${ }^{4}$, Rouhollah Yadollahi FARSANI ${ }^{2}$, Khalid ALMUTAIRI ${ }^{5}$, Hoa Xuan $\mathrm{AO}^{6}$, \\ Seyyed Jalaladdin HOSSEINI DEHSHIRI ${ }^{7}$, Seyyed Shahabaddin HOSSEINI DEHSHIRI ${ }^{8}$, \\ Ali MOSTAFAEIPOUR ${ }^{4,9}$, 10, Kuaanan TECHATO ${ }^{9,10^{*}}$ \\ ${ }^{1}$ Department of Medical Research, China Medical University Hospital, China Medical University, \\ Taichung, Taiwan \\ ${ }^{2}$ Department of Mechanical Engineering, Shahrekord Branch, Islamic Azad University, Shahrekord, Iran \\ ${ }^{3}$ Department of Architecture, Sepehr Institute of Higher Educational, Isfahan, Iran \\ ${ }^{4}$ Department of Industrial Engineering, Yazd University, Yazd, Iran \\ ${ }^{5}$ Applied College, Mechanical Engineering Technology, University of Hafr Al Batin, Hafr Al Batin, Saudi Arabia \\ ${ }^{6}$ Faculty of Economics, Tay Nguyen University, Buon Ma Thuot City, Dak Lak Province, Vietnam \\ ${ }^{7}$ Department of Industrial Management, Faculty of Management and Accounting, \\ Allameh Tabataba'i University, Tehran, Iran \\ ${ }^{8}$ Department of Mechanical Engineering, Sharif University of Technology, Tehran, Iran \\ ${ }^{9}$ Department of Sustainable Energy, Faculty of Environmental Management, \\ Prince of Songkla University, Songkhla, Thailand \\ ${ }^{10}$ Environmental Assessment and Technology for Hazardous Waste Management Research Center, \\ Faculty of Environmental Management, Prince of Songkla University, Songkhla, Thailand
}

Received 07 December 2020; accepted 28 April 2021

\footnotetext{
Highlights

CCR and BCC models in data envelopment analysis (DEA).

Solar heating system to provide sanitary hot water.

Environmental-technical assessments.
}

\begin{abstract}
A decrease in the utilization of fossil energies, mainly by replacing them with renewable energy sources (RESs), is regarded as a potential energy source in today's applications. RESs are broadly utilized for heating purposes and particularly with applications in solar water heater (SWH). Despite the accessibility of SWH technologies and their affordable prices in Iran, there is no comprehensive study to explain the potential of Iranian regions to supply hot water for household applications. This one-year work, hence, attempts the first dynamical simulation of a solar heating system to provide sanitary hot water (SHW) as well as hot water demanded to heat 47 stations in Iran. Weather data were extracted from METEONORM and environmental-technical analyses performed by thermal solar (TSOL) software. Stations were ranked based on CCR and BCC models in data envelopment analysis (DEA) method using GAMS V 24.1. As with results, a total of 223.1 MWh solar heat is generated annually from all stations that prevent the emission of $64.5 \mathrm{t} \mathrm{CO}_{2}$ every year. According to CCR and BCC models, Bandar Abbas, Chabahar, Fasa, Iranshahr, Kermanshah, Khoramabad, Sarab, Shahr-e-kord, Yasuj, Zanjan, and Zahedan are the best in this regard. Also according to the economic analysis, the average price of home solar heating in Iran is $0.160 \$ / \mathrm{kWh}$.
\end{abstract}

Keywords: solar water heater, Iran, data envelopment analysis (DEA), solar fraction, ranking.

${ }^{*}$ Corresponding author. E-mail: kuaanan.t@psu.ac.th 


\section{Introduction}

\section{Importance and necessity of SWH applications}

According to the International Energy Agency [IEA], the global use of energy sources will increase by $30 \%$ from 2011 to 2035 (IEA, 2017). The daily increase in energy consumption (on the one hand) and a decline in fossil energy sources and risk of associated air pollution (on the other hand) have driven researchers and industrialists to direct toward RESs. Figure 1 shows the capacity of installed solar energy (GW) for all over the world, and also by countries, from 2003 to 2019. The trend represents a dramatic growth, especially in recent years (Our World in Data, n.d.).

According to the International Solar Appointment, $\$ 1,000$ billion will allocate to promote the solar energy sector by 2030. As predicted by IEA's experts, a potential capacity for installing solar equipment in the world will increase to more than $700 \mathrm{GW}$ by 2022 , which is twice the current capacity of solar systems. Figure 2 shows the total primary energy supply by 2040 separately for different types of fuel. As illustrated in Figure 2, a total of 15\% of energy sources will allocate to RESs such as solar, wind, and geothermal energies by 2040 (IEA, 2015).

Domestic solar collectors have become more popular alongside the daily development of solar power plants. SWH, which convert solar energy into thermal energy, have no complicated structure and design and can be

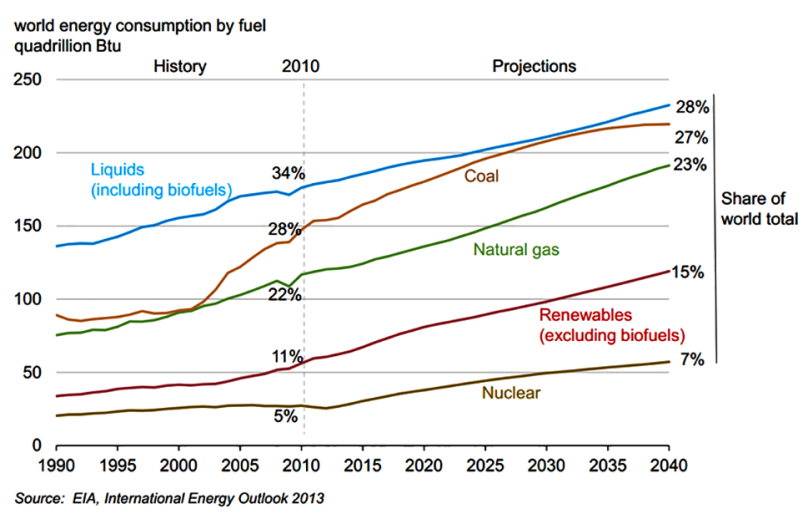

Figure 2. Total primary energy supply by different types of energy sources from 1990 to 2040 (IEA, 2017)

installed in limited spaces (such as rooftop) in compliance with other thermal systems (Modi et al., 2017; Pandey \& Chaurasiya, 2017; Khan et al., 2018).

Local SWH reduce the peak consumption of energy and emission of greenhouse gases and, contrarily, increase the efficiency of heating systems. The conversion of solar energy into thermal energy and the storage of this type of energy will also increase solar energy efficiency. Solar collectors can be used to supply heat in household applications. SWHs convert solar energy radiated into thermal energy and convey it to a circulating liquid such as water, air, or oil. This process has been a central design in SWH

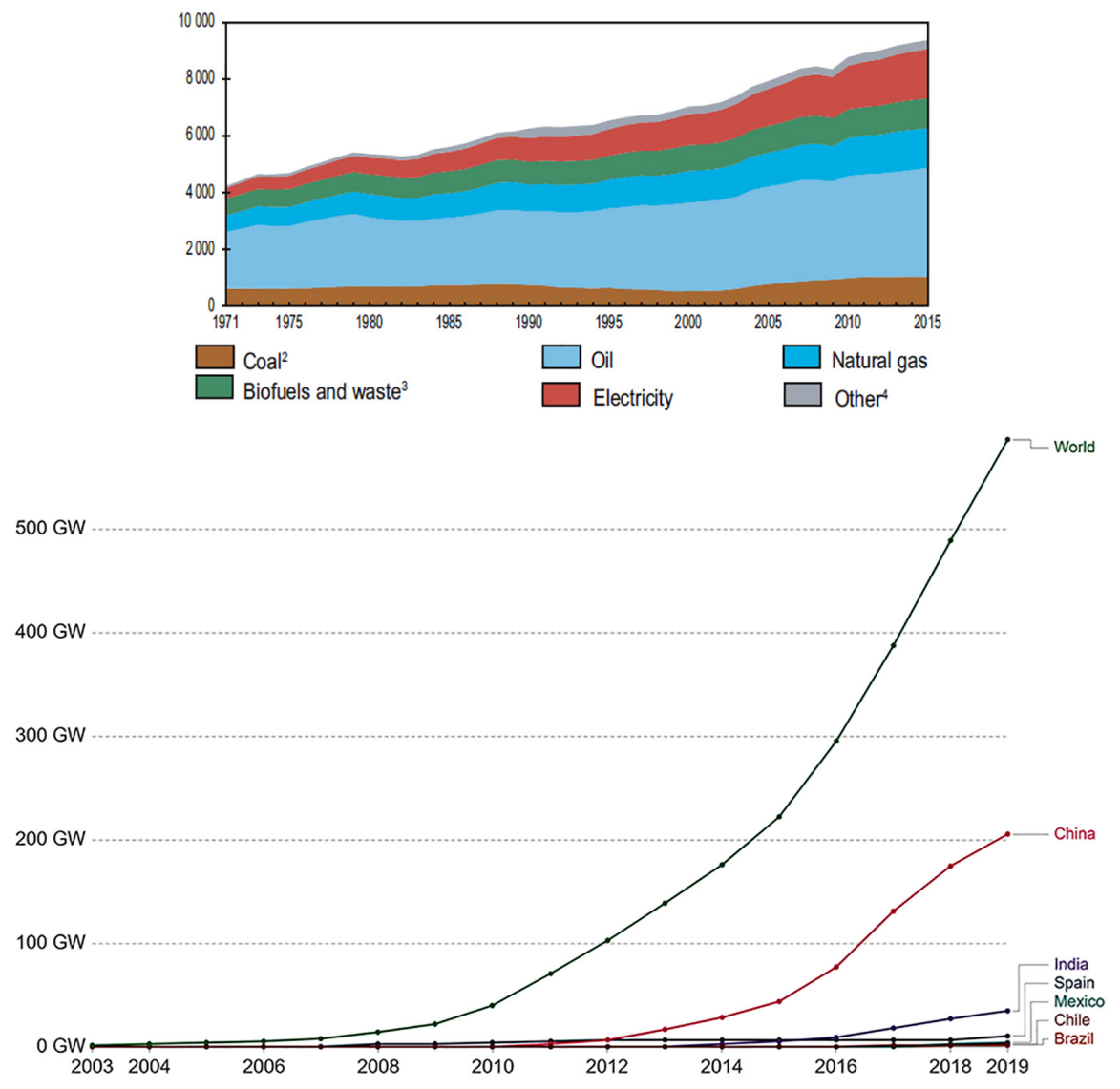

Figure 1. Installed Solar energy capacity, measured in gigawatts (GW) (Our World in Data, n.d.) 
for many years, but new studies are mainly attempting to increase the capacity of solar energy absorption (Iranmanesh et al., 2017; Khan et al., 2018; Mahbubul et al., 2018; Teamah et al., 2018). The importance of SWH has driven review studies to mainly reflect on features, designs, economic aspects, and applications of these systems (Jamar et al., 2016; Gautam et al., 2017). In recent studies, the use of phase change materials and the utilization of latent energy to improve the efficiency of these systems has been evaluated (Du et al., 2018; Khan et al., 2018). There have been many studies in Iran related to implanting renewable energy sources (Mostafaeipour \& Abesi, 2010; Mohammadi et al., 2014; Zarezade \& Mostafaeipour, 2016). There are numerous case studies conducted in different countries to assess the environmental consequences of these systems (Zhou \& Zhao, 2011; Mostafaeipour et al., 2017; Varghese \& Manjunath, 2017; Mamouri \& Benard, 2018; Uctug \& Azapagic, 2018).

\section{The study area}

Iran has considerable potential in solar energy sources due to its location between $25^{\circ}$ and $40^{\circ}$ latitudes and is ranked among the top countries in the world in terms of receiving solar energies. The average solar radiation in Iran has been estimated at between 1800 to $2200 \mathrm{kWh} / \mathrm{m}^{2}$-day, which stands above the international standard. This is even higher (up to $2800 \mathrm{kWh} / \mathrm{m}^{2}$-day) in the central and southern regions. Considerably, there have been reported averagely more than 280 sunny days in Iran every year (Marefati et al., 2018; Shahsavari et al., 2019). Household energy utilization in Iran accounts for a large portion of total energy consumed (Mollahosseini et al., 2017). This indicates a large portion of energy is wasted on heating, cooking, and so on, while it can help to create jobs and improve industrial productivity and also enhance the power to earn foreign currency. These, therefore, started a fundamental alteration in the energy system from 2004 after the targeting of subsidies on energy carriers. Figure 3 shows the rate of solar energy $\left(\mathrm{kWh} / \mathrm{m}^{2}\right)$ irradiated in different regions of Iran.

Studies show that the largest portion of water consumed in buildings is heated by natural gas, which is conveyed from the southern plateau of Iran to central and northern regions of the country at a very high cost. Due to the huge solar potential in Iran, part of water heating can be achieved using SWH. At least this huge potential can be applied to pre-heat water consumed in hybrid solarnatural gas systems.

\section{Literature review}

Due to the high solar energy potential, numerous case studies have been carried out on the utilization of SWH in Iran.

Mostafaeipour et al. (2017) studied the use of SWH in some arid regions of Iran. Accordingly, they selected Yazd provinces as the study area, which is located nearly in the center of Iran. They attempted to find factors affecting the

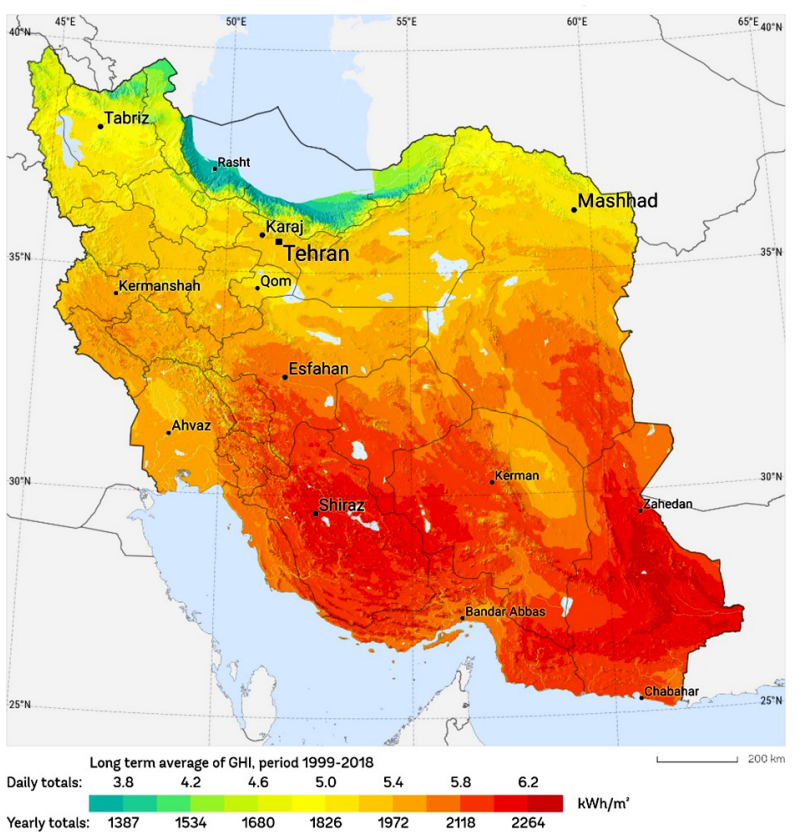

Figure 3. Global horizontal irradiation of Iran in $\mathrm{kWh} / \mathrm{m}^{2}$ (Solar resource maps of Iran, 2020)

use of SWH in the area and found that several factors such as geographical location, social aspects, economic aspects, financial supports, infrastructures, and technical knowledge considerably affect the popularity of using these systems in buildings. Finally, they stated that the promotion of general and technical knowledge and financial support are two principal factors to encourage building owners to use this clean technology.

A hybrid system of photovoltaics and household SWH was evaluated by Mohammadi et al. (2017) in four different Iranian cities including Bandar Abbas and Kerman (respectively in Hormozgan and Kerman provinces in southern Iran), Tabriz (East Azerbaijan province in northwest of Iran) and Tehran (Tehran province in the center and north of Iran) during four seasons. They reported that due to the reduction in solar cell efficiency with increasing temperature, a parallel cooling system used to reduce the temperature of these cells can help to enhance cell efficiency and improve the capacity of a home heating system. The maximum thermal energy generated by the system was reported by $16 \mathrm{kWh}$ per day in Bandar Abbas.

Mathematical modeling of a SWH system was performed on a bird-growing building in Tehran using MATLAB by Yousef Nezhad and Hoseinzadeh (2017). The thermal capacity of all systems was compared regarding two separate heaters in the tank. The results showed that the surface of the collector considerably affects the thermal efficiency of the SWH system. Also, the use of a nonsolar heating source to heat the tank to the temperature of interest during a shorter period can help to improve the performance of a whole system. After increasing the number of heaters in the storage tank, the inlet and outlet temperature of the heat exchanger will reach a near range and thereby the efficiency of the heat exchanger will drop. 
In their numerical study using ANSYS CFX and a laboratory model, Sardouei et al. (2018) studied the impact of output temperature distribution and surface modulus of the SWH on a photovoltaic-thermal (PVT) hybrid collector, particularly in low flow rate. The results showed that an increase in the flow rate from 30 to $90 \mathrm{l} / \mathrm{h}$ can decrease the temperature by $6 \%$ (on the outlet) and $18 \%$ (on the collector's surface). Also, the highest efficiency of $56 \%$ was reported at the flow rate of $90 \mathrm{l} / \mathrm{s}$.

\section{The innovation of the research}

As with previous studies, the novelties of this work are as following:

First, and to our knowledge, no comprehensive study has been conducted so far to evaluate the heat generation potential and capacity of SWH to prevent the emission of domestic pollution in Iran. Second, we can determine the most optimal regions in Iran for the application of SWH according to the results of this study. Third, this work attempts the first classification (ranking) of Iranian stations in terms of usability of SWH. Fourth, although the present work is a case study on the study of different stations in the climates of Cold, Very cold, Moderate \& rainy, Semi moderate \& rainy, Semi-arid, Hot \& dry, Very hot \& dry, and Very hot \& humid in Iran, but the results of each of these stations, due to the great climatic diversity in Iran, can be generalized to places with similar climatic conditions in terms of radiation and ambient temperature, etc. around the world. And fifth, despite the fact that the present work is for Iran, but the method used for analysis and technical-economic-environmental analysis of the results as well as the use of DEA ranking methods can be used for any station in any part of the world.

\section{Methodology}

\subsection{TSOL software}

TSOL is a professional simulation software for designing and planning solar thermal systems. With this software, the simulation and calculation of these systems have been easier because it provides multiple tools, components of solar systems, and associated parts such as hot water source, swimming pool, thermal process, and more. Calculations in TSOL are based on energy balance and supplying final demand using hourly weather data (Jahangiri et al., 2018).

Total solar energy radiated on the surface of a collector is equal to the sum of direct and diffused radiations. Direct radiation is available in climatic files. The rate of diffused radiation on the surface of a collector under an angle of $\alpha$ and the air clearness index $K_{t}$ are calculated respectively by the following equations (Pahlavan et al., 2018):

$$
\begin{aligned}
& 0 \leq k_{t} \leq 0 \cdot 3 \quad: \frac{I_{d}}{I}=1 \cdot 02-0 \cdot 245 k_{t}+0 \cdot 0123 \sin \alpha ; \\
& 0 \cdot 3<k_{t} \leq 0 \cdot 78: \frac{I_{d}}{I}=1 \cdot 4-1 \cdot 749 k_{t}+0 \cdot 177 \sin \alpha ;
\end{aligned}
$$

$k_{t} \geq 0 \cdot 78: \frac{I_{d}}{I}=0 \cdot 486 k_{t}-0 \cdot 182 \sin \alpha$,

where $I$ is hourly total radiation on a horizontal surface (in $\mathrm{KJ} / \mathrm{m}^{2}$ ) and $I_{d}$ is hourly diffuse radiation on a horizontal surface (in $\mathrm{KJ} / \mathrm{m}^{2}$ ).

Note that some of the energy radiated on the surface of a collector will be lost. The energy balance in a collector is calculated by the following equation (Pahlavan et al., 2018):

$$
\begin{aligned}
& \rho=G_{d i r} \cdot \eta_{0} \cdot f_{\text {IAM }}+G_{\text {diff }} \cdot \eta_{0} \cdot f_{\text {IAM.diff }}- \\
& k_{0}\left(T_{k m}-T_{A}\right)-k_{q}\left(T_{k m}-T_{A}\right)^{2},
\end{aligned}
$$

where $G_{d i r}$ is part of solar irradiation striking a tilted surface, $\eta_{0}$ is zero-loss collector efficiency, $f_{\text {IAM }}$ is incident angle modifier, $G_{d i f f}$ is diffused solar irradiation striking a tilted surface, $f_{\text {IAM, diff }}$ is diffused incident angle modifier, $k_{0}$ is simple heat transfer coefficient (in $\frac{w}{m^{2}-k}$ ), $T_{c m}$ is the average temperature of a collector, $T_{A}$ is air temperature, and $k_{q}$ is quadratic heat transfer coefficient (in $\left.\frac{w}{m^{2}-k^{2}}\right)$

The software considers the rate of $\mathrm{CO}_{2}$ prevented from emission for burning natural gas at $5.14355 \mathrm{~g}$ per KJ energy generated (Pahlavan et al., 2018). The rate of energy supplied from a collector is calculated by dividing energy supplied by the solar system to the standby tank on total energy supplied for standby tank (solar system + auxiliary heating) by the following equation (Pahlavan et al., 2018):

$$
\begin{aligned}
& \text { Solar fraction.total }= \\
& \frac{Q_{C L . D H W}+Q_{S . H L}}{Q_{C L . D H W}+Q_{S . H L}+Q_{A u x H . D H W}+Q_{A u x H . H L}} .
\end{aligned}
$$

Other equations used in a simulation (as illustrated schematically in Figure 4) includes (Pahlavan et al., 2018):

$$
\begin{aligned}
& \text { Solar fraction } D H W=\frac{Q_{C L . D H W}}{Q_{C L . D H W}+Q_{A u x H . D H W}} ; \\
& \text { Solar fraction heating }=\frac{Q_{S . H L}}{Q_{S . H L}+Q_{A u x H . H L}} .
\end{aligned}
$$

In the present work, economic calculations are based on the Net present value (NPV) method. This parameter, which is one of the main ways to evaluate an investment, is also one of the most widely used techniques and is calculated by the following equation:

$$
N P V=R_{t}-C .
$$

In the above equation, $R_{t}$ is the total revenue and $C$ is the cost of the SWH system, each of which is calculated by the following equations:

$$
C=C_{0}+\sum_{n=1}^{N} \frac{C_{O \& M} \times(1+e)^{n}}{(1+d)^{n}} ;
$$




$$
R_{t}=\frac{Q_{u}}{\eta_{h}} \sum_{n=1}^{N} \frac{(1+e)^{n}}{(1+d)^{n}} .
$$

In the above equations $C_{0}$ is the total purchase cost, $C_{\mathrm{O \& M}}$ is the total annual operating and maintenance costs, $\mathrm{e}$ is the useful life, $\mathrm{d}$ is the rate of decline, $\mathrm{n}$ is the number of years, $\eta_{h}$ is the efficiency of the auxiliary boiler and $Q_{u}$ is the useful energy collected by the solar collectors. The Table 1 lists the parameters required for economic calculations.

Table 1. Information required for economic calculations in the software

\begin{tabular}{|l|c|}
\hline \multicolumn{1}{|c|}{ Parameter } & Value \\
\hline Lifespan & 20 year \\
\hline Investment & $200 \$ / \mathrm{m}^{2}$ \\
\hline Interest on capital & $18 \%$ \\
\hline Specific fuel cost & $0.012 \$ / \mathrm{m}^{3}$ \\
\hline Specific electricity cost & $0.04 \$ / \mathrm{kWh}$ \\
\hline Operating and maintenance cost & $50 \$$ \\
\hline
\end{tabular}

\subsection{DEA method}

The DEA is comprehensive method which tries to evaluate the performance of different decision making units (DMUs). CCR model is a mathematical formulation of DEA somehow some DMUs are predefined with certain input and output data. The CCR model has a constant return to scale and tries to choose optimal weights for input and output variables in each DMU to control the efficiency of other DMUs. This model has been proposed in two input and output states and under three fractional, multiple-based, and envelopment-based forms. A multiple-based form that is the most applicable form of CCR is defined as Equation (11):

s.t

$$
\begin{aligned}
& \operatorname{Min} \theta+\varepsilon\left[\sum_{i=1}^{m} s_{i}^{-}+\sum_{r=1}^{s} s_{r}^{+}\right] ; \\
& y_{r p}=\sum_{j=1}^{n} y_{r j} \lambda_{j}-s_{r}^{+} \quad r=1, \ldots, s ; \\
& \theta_{x_{i p}}=\sum_{j=1}^{n} x_{i j} \lambda_{j}-s_{i}^{-} \quad i=1, \ldots, m ; \\
& \lambda_{j} \geq 0 \quad j=1, \ldots, n ; \\
& s_{r}^{+}, s_{i}^{-} \geq 0 \quad r=1, \ldots, s \quad i=1, \ldots, m .
\end{aligned}
$$

According to Equation (11), in this model, the choice of each allowed $\lambda$ vector will create an upper bound for outputs and lower bound for inputs of each DMU. Equation (11) shows that the multiple-based model allows determining a given value of $\lambda_{j}$ for each inefficient unit. As with Equation (11), the optimal solution of the CCR model, therefore, indicates the relative efficiency of DMU. Each DMU is efficient when $\theta$ is equal to 1 for it, and hence, DMUs with values lower than 1 are not efficient (Liu et al., 2000).

The $\mathrm{BBC}$ model has its name from its developers Banker, Charnes, and Cooper. Unlike the CCR model, the $\mathrm{BBC}$ model considers variable return to scale. The use of a variable return to scale allows a detailed analysis by calculation of the efficiency of DMUs. The BBC model is designed based on the principles adopted in the CCR model. In the input-based model, the degree of efficiency is analyzed by a reduction in inputs. But in the outputbased model, the rate of efficiency is analyzed by an increase in inputs. Accordingly, the multiple-based model that is a combination of input- and output-based models are applied. The multiple-based model of BBC is expressed as the Equation (12):

$$
\operatorname{Min} \theta+\varepsilon\left[\sum_{i=1}^{m} s_{i}^{-}+\sum_{r=1}^{s} s_{r}^{+}\right]
$$

s.t

$$
\begin{aligned}
& y_{r p}=\sum_{j=1}^{n} y_{r j} \lambda_{j}-s_{r}^{+} \quad r=1, \ldots, s ; \\
& \theta_{x_{i p}}=\sum_{j=1}^{n} x_{i j} \lambda_{j}-s_{i}^{-} \quad i=1, \ldots, m ; \\
& \sum_{j=1}^{n} \lambda_{j}=1 ; \\
& \lambda_{j} \geq 0 \quad \quad j=1, \ldots, n ; \\
& s_{r}^{+}, s_{i}^{-} \geq 0 \quad r=1, \ldots, s \quad i=1, \ldots, m .
\end{aligned}
$$

In the input-based BBC model, the goal is to calculate efficiency under decreased inputs and constant outputs. Accordingly, we can consider the DMU to be an efficient one. Contrarily, in the output-based BBC model, the goal is to calculate efficiency under decreased outputs and constant inputs. Under this mood, the DMU will also reach an efficient level. The multiple-model based algorithm both in the CCR and BBC models can combine input-based and output-based approaches. The reason for choosing a multiple-model based approach is that the management has no control over the rate of input in some cases and its rate is given and constant beforehand and vice versa. In some cases, the rate of input and output is given and constant whilst the rate of generation (output) is considered as the decision-making variable (Cooper et al., 2011).

\section{Simulation data}

Thermal data, geographical location, the temperature of the urban water network and total annual global irradiation in stations under study are factors required for simulation (Table 2). Note that data summarized in Table 2 are extracted from METEONORM software.

The average daily consumption of SHW was $110 \mathrm{l}$. The temperature of SHW was $60^{\circ} \mathrm{C}$ and we considered that the SHW is consumed throughout the year. The thermal load of the used space, the temperature of space under 
Table 2. Data over stations under study

\begin{tabular}{|c|c|c|c|c|c|}
\hline Station & Latitude & Longitude & $\begin{array}{l}\text { Total annual } \\
\text { irradiation } \\
\left(\mathrm{kWh} / \mathrm{m}^{2}\right)\end{array}$ & $\begin{array}{c}\text { Diffuse } \\
\text { radiation percentage } \\
(\%)\end{array}$ & $\begin{array}{l}\text { Cold water temperature } \\
(\text { Feb/Aug }) \\
\left({ }^{\circ} \mathrm{C}\right)\end{array}$ \\
\hline Abadan & 30.4 & -48.3 & 1577.0 & 55.4 & $22.5 / 29.5$ \\
\hline Abadeh & 31.2 & -52.7 & 1841.6 & 49 & $11.5 / 18$ \\
\hline Ahar & 38.4 & -47.1 & 1866.9 & 40.6 & $8 / 14$ \\
\hline Ahvaz & 31.3 & -48.7 & 1532.4 & 56 & $22.5 / 30$ \\
\hline Aligoodarz & 32.4 & -49.7 & 1668.5 & 51.4 & $9 / 16.5$ \\
\hline Arak & 34.1 & -49.8 & 1839.4 & 45.6 & $10.5 / 18$ \\
\hline Ardebil & 38.3 & -48.3 & 1757.4 & 45.4 & $7 / 12.5$ \\
\hline Bandar Abbas & 27.2 & -56.4 & 1918.5 & 45.7 & $25 / 29.5$ \\
\hline Bandar-e-Anzali & 37.5 & -49.5 & 1399.9 & 54.1 & $14.5 / 19$ \\
\hline Bandar-e-Lenge & 26.6 & -54.8 & 1968.6 & 43.9 & $25.5 / 30$ \\
\hline Birjand & 32.9 & -59.2 & 2062.9 & 41.7 & $13.5 / 20.5$ \\
\hline Bushehr & 29.0 & -50.8 & 1626.7 & 53.7 & $23 / 27.5$ \\
\hline Chabahar & 25.3 & -60.6 & 2106.2 & 39.0 & $27 / 30.5$ \\
\hline Dezful & 32.4 & -48.4 & 1546.1 & 53.5 & $22.5 / 30$ \\
\hline Esfahan & 32.6 & -51.7 & 1826.3 & 45.2 & $12.5 / 20$ \\
\hline Fasa & 29.0 & -53.7 & 1870.1 & 45.3 & $16 / 23$ \\
\hline Ghazvin & 36.3 & -50.0 & 1808.0 & 43.3 & $10.5 / 17.5$ \\
\hline Ghoochan & 36.9 & -54.3 & 1624.7 & 48.0 & $9.5 / 16.5$ \\
\hline Gorgan & 36.8 & -54.5 & 1554.9 & 49.5 & $15 / 20.5$ \\
\hline Hamedan & 34.9 & -48.5 & 1853.2 & 44.7 & $8.5 / 16$ \\
\hline Iranshahr & 27.2 & -60.7 & 1979.4 & 41.0 & $24.5 / 31.5$ \\
\hline Kashan & 34.0 & -51.4 & 1875.7 & 40.2 & $15.5 / 23.5$ \\
\hline Kashmar & 35.2 & -58.5 & 1796.6 & 42.1 & $14.5 / 22$ \\
\hline Kerman & 30.3 & -57.0 & 1906.0 & 45.3 & $14.5 / 21$ \\
\hline Kermanshah & 34.3 & -47.1 & 1875.3 & 42.0 & $12 / 19.5$ \\
\hline Khoramabad & 33.5 & -48.4 & 1843.0 & 43.6 & $13.5 / 20.5$ \\
\hline Khoy & 38.6 & -45.0 & 1912.9 & 38.5 & $9 / 16.5$ \\
\hline Mako & 39.3 & -44.4 & 1615.3 & 48.0 & $7 / 14.5$ \\
\hline Maragheh & 37.4 & -46.3 & 1923.1 & 39.7 & $9.5 / 17$ \\
\hline Mashhad & 36.3 & -59.6 & 1694.2 & 44.7 & $12 / 19.5$ \\
\hline Oroomieh & 37.5 & -45.1 & 1979.9 & 39.1 & $8 / 15$ \\
\hline Ramsar & 36.9 & -50.7 & 1299.2 & 60.7 & $14.5 / 19$ \\
\hline Rasht & 37.3 & -49.6 & 1388.8 & 55.5 & $14 / 19$ \\
\hline Sabzevar & 36.2 & -57.7 & 1744.3 & 42.9 & $14 / 22$ \\
\hline Sanandaj & 35.3 & -47.0 & 1886.3 & 42.5 & $10.5 / 18$ \\
\hline Sarab & 37.9 & -47.5 & 1853.5 & 40.8 & $5.5 / 12.5$ \\
\hline Semnan & 35.6 & -53.6 & 1925.9 & 40.9 & $14.5 / 22.5$ \\
\hline Shahr-e-kord & 32.3 & -50.9 & 1864.7 & 47.6 & $8 / 15$ \\
\hline Shahroud & 36.4 & -55.0 & 1904.0 & 41.7 & $11.5 / 19$ \\
\hline Shiraz & 29.6 & -52.6 & 1879.7 & 46.0 & $15.5 / 22.5$ \\
\hline Tabriz & 38.1 & -46.3 & 1885.8 & 39.6 & $9.5 / 17$ \\
\hline Tehran & 35.7 & -51.2 & 1818.5 & 42.0 & $14.5 / 22$ \\
\hline Torbat-e Hrydarieh & 35.3 & -59.2 & 1779.6 & 43.2 & $10.5 / 18$ \\
\hline Yasuj & 30.8 & -51.7 & 1819.3 & 48.9 & $11.5 / 18.5$ \\
\hline Yazd & 31.9 & -54.4 & 1960.3 & 40.9 & $16.5 / 24$ \\
\hline Zahedan & 29.5 & -60.9 & 2062.8 & 43.0 & $17 / 23.5$ \\
\hline Zanjan & 36.7 & -48.5 & 1862.3 & 42.3 & $8 / 15$ \\
\hline
\end{tabular}


study, and effective heated area were respectively $10 \mathrm{~kW}$, $21{ }^{\circ} \mathrm{C}$, and $80 \mathrm{~m}^{2}$. Windows were double glazed and the area of northern, eastern, southern, and western windows was respectively $1.6,4,8$, and $5.6 \mathrm{~m}^{2}$. The amount of heat obtained from internal heating systems was considered to be $5 \mathrm{~W} / \mathrm{m}^{2}$. Also, the need for heating of the building assumed to be equal in all months except for June and July. The building's walls were of medium type and the solar collector used and associated equipment such as buffer tanks, piping length, boiler and etc., considered the same for comparison of all stations.

A standard flat plate SWH with an area of $20 \mathrm{~m}^{2}$ and the solar azimuth angle of zero was used. Buffer tanks intended to heat SHW and space were respectively of double-coil and single-coil type with 300 and $1000 \mathrm{l}$ capacity (Figure 4). A gas boiler with a nominal capacity of $9 \mathrm{~kW}$ was used. Intermediate fluids were water and polypropylene glycol with a ratio of 60 to 40 and a flow rate of $40 \mathrm{l} / \mathrm{h}$. The difference between the forward and reverse temperature was $20^{\circ} \mathrm{C}$ (for high heating of space) and $15^{\circ} \mathrm{C}$ for other conditions. The system is schematically illustrated in Figure 4. The angle of positioning solar collectors was equal to the latitude of the respective region.

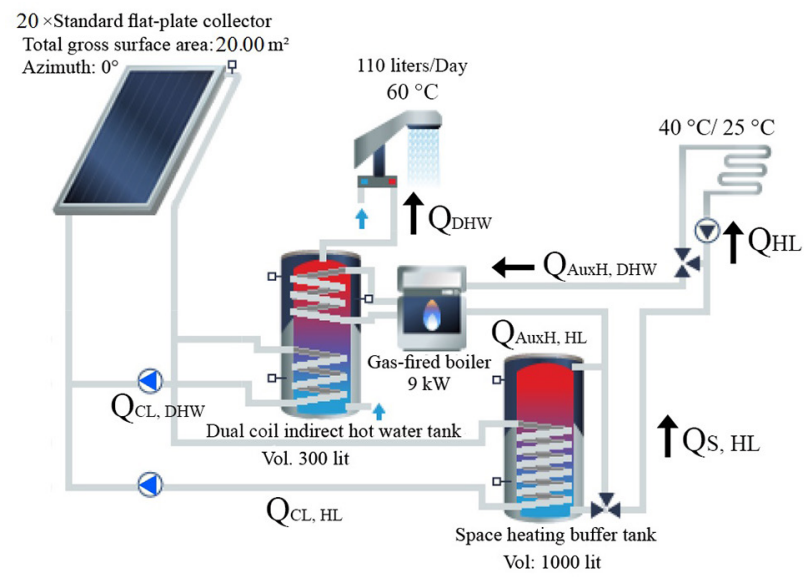

Figure 4. Schematic of solar system with bivalent storage tank (internal heat exchanger)

To implement DEA-BBC and DEA-CCR models, it is first necessary to determine components of the DEA method. In this method, 47 stations in Iran are considered as decision-making units (DMUs). Figure 5 shows the implementation of the DEA model.

Given accessibility to input and output data of each DMU (Table 3), the efficiency of each DMU can be calculated by the optimization of the BBC and CCR models. To do this, we worked with GAMS (v. 24.1). The results are summarized in the related figure.

\section{Results}

In the results section, all the parameters of Table 3 are explained and the most suitable and unsuitable stations in terms of each parameter of Table 3 are introduced. Also, the total annual and monthly average of significant parameters such as fuel consumption, pollutant production, etc. have been calculated. Ranking results figure also uses two different models BCC and CCR for the DEA method, ranking the evaluated stations. Also the results of the study of economic parameters net present value (NPV) and cost of energy (COE) are given in Table 4, based on which the payback time for each station and the average cost per kWh of solar heat produced in Iran are calculated.

\subsection{Energy and enviro analysis}

As with the results of Table 3, only in the station of Chabahar, solar energy has been able to supply $100 \%$ of thermal demands due to the lower demand for thermal energy to heat space in this station and also adequate solar radiation. According to Table 3, stations of Bandar-e-Lengeh (96\%) and Bandar Abbas (91\%) stands next ranks for supplying thermal demands by SWH systems. The average supply of total thermal demand by SWHs for all stations is $38.3 \%$.

According to Table 3, the total energy supplied by SWHs for space heating in all stations is $105,857 \mathrm{kWh}$, with an average of $2252.3 \mathrm{kWh}$ per each station. In this regard, Sarab station has generated the highest energy through the SWH system by $3428 \mathrm{kWh}$. The average percentage of energy supplied for space heating in all stations is $25.2 \%$.

In association with the supply of SHW in all stations, according to Table 3, a total of 127,247 kWh energy has been generated by SWHs, which averagely supply $96.2 \%$ of the demand of all stations. The average generation of energy for SHW in all stations is $2707.4 \mathrm{kWh}$. In this regard, Bandar Abbas, Bandar-e-Lengeh and Iranshahr stations have been able to supplied $100 \%$ of their needs by SWHs. Also in this regards, Sarab station has generated the highest amount of energy by the SWH system by $3019 \mathrm{kWh}$. The least energy generated for SHW (2243 kWh) was observed in Dezful station. Due to the use of the SWH system which diminishes the use of fossil fuels, around $64.5 \mathrm{t}$ $\mathrm{CO}_{2}$ is prevented from emission annually.

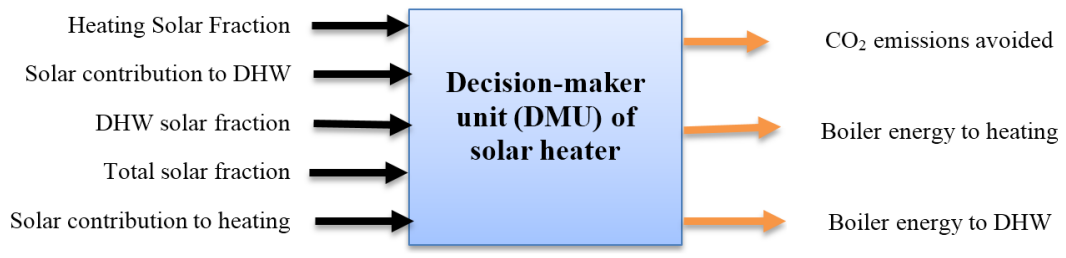

Figure 5. The overall structure of DMUs in the evaluation of Iran's stations 
Table 3. Results of using SWH in all stations

\begin{tabular}{|c|c|c|c|c|c|c|c|c|}
\hline Station & $\begin{array}{c}\text { Total solar } \\
\text { fraction }(\%)\end{array}$ & $\begin{array}{c}\text { Solar } \\
\text { Contribution } \\
\text { To heating } \\
(\mathrm{kWh})\end{array}$ & $\begin{array}{l}\text { Heating } \\
\text { Solar } \\
\text { Fraction } \\
\quad(\%)\end{array}$ & $\begin{array}{l}\text { Solar } \\
\text { Contribution } \\
\text { to } \mathrm{DHW} \\
(\mathrm{kWh})\end{array}$ & $\begin{array}{l}\text { DHW solar } \\
\text { fraction } \\
(\%)\end{array}$ & $\begin{array}{c}\mathrm{CO}_{2} \\
\text { emission } \\
\text { Avoided } \\
(\mathrm{kg})\end{array}$ & $\begin{array}{l}\text { Boiler } \\
\text { energy to } \\
\text { heating } \\
(\mathrm{kWh})\end{array}$ & $\begin{array}{c}\text { Boiler } \\
\text { energy } \\
\text { to DHW } \\
(\mathrm{kWh})\end{array}$ \\
\hline Abadan & 46 & 991 & 21 & 2331 & 96 & 1044 & 3773 & 104 \\
\hline Abadeh & 36 & 2989 & 23 & 2784 & 96 & 1537 & 10049 & 115 \\
\hline Ahar & 31 & 2976 & 18.6 & 2955 & 96 & 1554 & 13013 & 157 \\
\hline Ahvaz & 46 & 968 & 21 & 2265 & 94 & 1015 & 3669 & 147 \\
\hline Aligoodarz & 27 & 2074 & 14.4 & 2650 & 90 & 1275 & 12340 & 278 \\
\hline Arak & 35 & 2471 & 20 & 2796 & 95 & 1420 & 9835 & 141 \\
\hline Ardebil & 32 & 3064 & 19.8 & 2961 & 95 & 1560 & 12421 & 141 \\
\hline Bandar Abbas & 91 & 511 & 64 & 2442 & 100 & 1012 & 284 & 8.3 \\
\hline Bandar-e-Anzali & 23 & 1390 & 9.7 & 2489 & 91 & 1110 & 12919 & 260 \\
\hline Bandar-e-Lenge & 96 & 378 & 76 & 2421 & 100 & 980 & 121 & 2.4 \\
\hline Birjand & 47 & 3215 & 32 & 2865 & 99 & 1641 & 6885 & 18.2 \\
\hline Bushehr & 66 & 561 & 28 & 2373 & 96 & 986 & 1455 & 88 \\
\hline Chabahar & 100 & 76 & 101 & 2394 & 100 & 902 & -0.70 & 0 \\
\hline Dezful & 46 & 866 & 20 & 2243 & 93 & 986 & 3462 & 158 \\
\hline Esfahan & 36 & 2744 & 22 & 2746 & 97 & 1478 & 9515 & 97 \\
\hline Fasa & 44 & 2899 & 29 & 2659 & 98 & 1521 & 7018 & 66 \\
\hline Ghazvin & 35 & 2740 & 21 & 2852 & 97 & 1492 & 10407 & 95 \\
\hline Ghoochan & 33 & 2872 & 20 & 2852 & 96 & 1517 & 11329 & 110 \\
\hline Gorgan & 33 & 1952 & 17.2 & 2653 & 96 & 1295 & 9418 & 109 \\
\hline Hamedan & 36 & 2857 & 22 & 2884 & 96 & 1510 & 10083 & 128 \\
\hline Iranshahr & 76 & 1092 & 50 & 2401 & 100 & 1106 & 1087 & 10.4 \\
\hline Kashan & 39 & 2287 & 23 & 2685 & 98 & 1386 & 7730 & 65 \\
\hline Kashmar & 34 & 1953 & 18.1 & 2701 & 97 & 1319 & 8838 & 74 \\
\hline Kerman & 45 & 2738 & 30 & 2739 & 98 & 1491 & 6494 & 69 \\
\hline Kermanshah & 36 & 2864 & 22 & 2806 & 97 & 1524 & 10063 & 79 \\
\hline Khoramabad & 35 & 2830 & 21 & 2722 & 96 & 1499 & 10435 & 100 \\
\hline Khoy & 34 & 2644 & 19.6 & 2927 & 96 & 1488 & 10823 & 107 \\
\hline Mako & 28 & 2601 & 15.9 & 2906 & 96 & 1456 & 13774 & 130 \\
\hline Maragheh & 31 & 2732 & 17.6 & 2927 & 97 & 1511 & 12756 & 79 \\
\hline Mashhad & 33 & 2051 & 17.4 & 2717 & 95 & 1320 & 9727 & 146 \\
\hline Oroomieh & 33 & 3319 & 20 & 2986 & 97 & 1647 & 12994 & 96 \\
\hline Ramsar & 23 & 1324 & 9.8 & 2429 & 90 & 1075 & 12224 & 282 \\
\hline Rasht & 26 & 1490 & 11.7 & 2550 & 92 & 1152 & 11206 & 214 \\
\hline Sabzevar & 34 & 2182 & 19.1 & 2699 & 97 & 1359 & 9214 & 95 \\
\hline Sanandaj & 34 & 2892 & 21 & 2858 & 97 & 1526 & 10891 & 93 \\
\hline Sarab & 33 & 3428 & 21 & 3019 & 96 & 1652 & 12890 & 142 \\
\hline Semnan & 34 & 2412 & 19.5 & 2750 & 98 & 1436 & 9949 & 49 \\
\hline Shahr-e-kord & 36 & 3215 & 24 & 2838 & 93 & 1575 & 10364 & 198 \\
\hline Shahroud & 34 & 2809 & 20 & 2880 & 98 & 1540 & 11080 & 60 \\
\hline Shiraz & 41 & 2624 & 26 & 2661 & 97 & 1457 & 7593 & 86 \\
\hline Tabriz & 30 & 2572 & 17.3 & 2842 & 95 & 1455 & 12272 & 135 \\
\hline Tehran & 33 & 2102 & 17.8 & 2719 & 97 & 1353 & 9725 & 73 \\
\hline $\begin{array}{l}\text { Torbat-e } \\
\text { Hrydarieh }\end{array}$ & 33 & 2264 & 17.9 & 2803 & 95 & 1381 & 10360 & 137 \\
\hline Yasuj & 32 & 2707 & 19.3 & 2702 & 94 & 1457 & 11286 & 176 \\
\hline Yazd & 46 & 2327 & 28 & 2720 & 99 & 1415 & 6013 & 17.6 \\
\hline Zahedan & 54 & 2551 & 37 & 2693 & 99 & 1466 & 4418 & 39 \\
\hline Zanjan & 33 & 3253 & 21 & 2952 & 96 & 1618 & 12351 & 118 \\
\hline
\end{tabular}


However, since the energy generated by SWHs cannot supply all thermal demands of households, the use of an auxiliary gas boiler is necessary. According to Table 3, there is a major need for a gas boiler to supply thermal energy for space heating. Generally, 414,552 kWh of heat for space heating and $5093 \mathrm{kWh}$ of heat for SHW were been produced by the auxiliary gas boiler. Also, the highest need for an auxiliary gas boiler to generate thermal energy of 13,774 kWh annually for space heating was observed at Mako station. The highest need for an auxiliary gas boiler to generate thermal energy of $282 \mathrm{kWh}$ annually for SHW was observed at Ramsar station.

The amount of heat required and the heat supplied by SWH for the Chabahar station are shown in Figure 6. Based on the results of Figure 6, it can be seen that of the $2470 \mathrm{kWh}$ of heat required, all of it is supplied by SWHs. Also, the maximum and minimum required weekly heat with values of about $102 \mathrm{kWh}$ and about $38 \mathrm{kWh}$ occur in February (third week) and July (third week), respectively. As the results of Figure 6 show and expected, the maximum required heat is in the cold months of the year (November to April) and in summer the required heat reaches its minimum.
Figure 7 shows a schematic of the energy balance between the components of the solar heating system for the Chabahar station. The results show that the received radiation on the surface of solar collectors is equal to 45.73 MWh, which indicates the good condition of radiation at Chabahar station. Of course, it should be noted that the optical and heat losses of the collectors in this station are very high and are 13.64 MWh and 24.187 MWh, respectively, which leads to a net annual production of 7.9 MW of heat by SWHs, respectively. Another point that can be seen from the schematic of the energy balance of the solar heating system is that the main losses of the system are first in the tanks and then in the piping system, so that for Chabahar station these losses are $4184 \mathrm{kWh}$ and $2181 \mathrm{kWh}$, respectively.

\subsection{Ranking analysis}

Regarding the need for ranking, it should be noted that in some places the percentage of thermal energy supply is low, while this low percentage is due to higher heat demand and not less production. Also, the effect of some parameters, such as the production of pollutants from the gas-fired boiler, which has a negative effect, should be

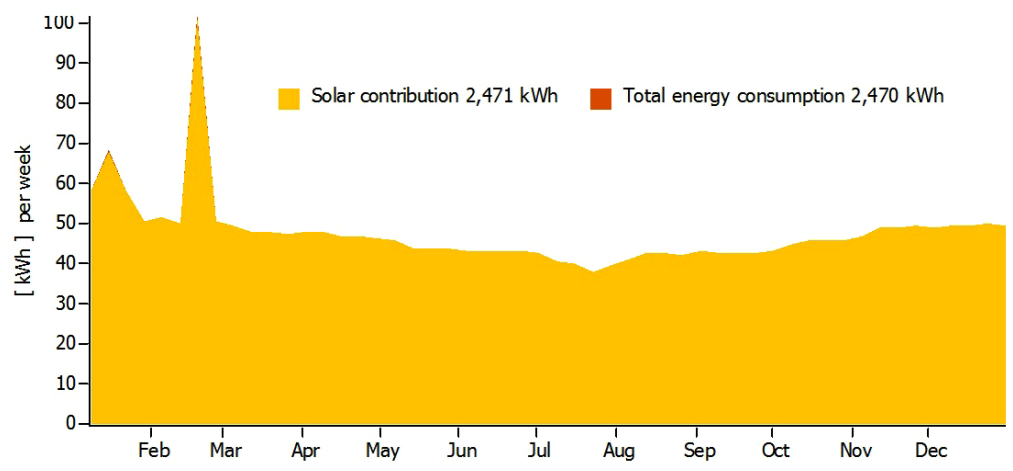

Figure 6. Weekly heat required and supplied by SWHs for Chabahar station

1
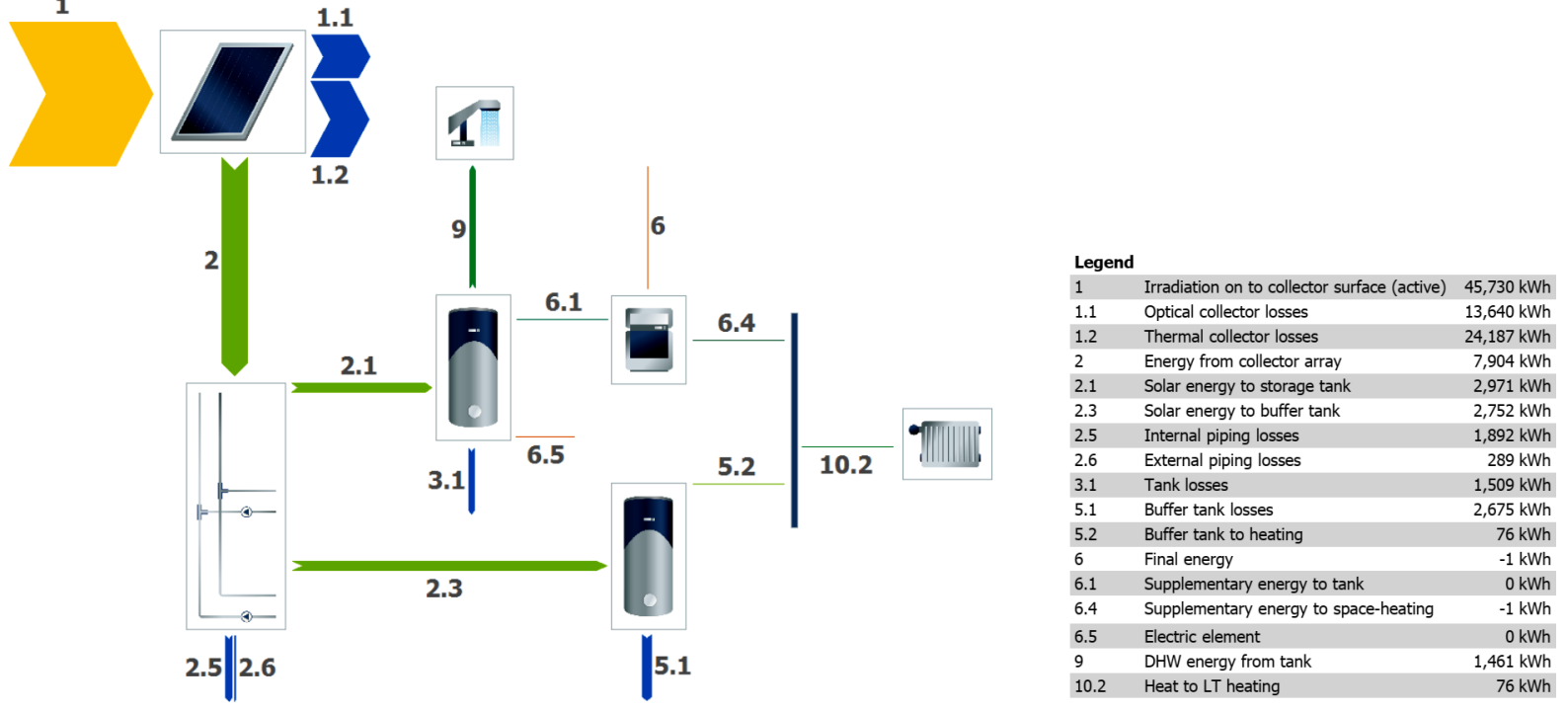

Figure 7. Weekly heat required and supplied by SWHs for Chabahar station 
measured by a parameter such as the amount of heat production, which has a positive effect. Therefore, the need for ranking is clearly seen.

Figure 8 shows that the $\mathrm{BBC}$ model has indicated 12 stations with 100\% efficiency. These include Bandar Abbas, Bandar-e-Lengeh, Chabahar, Fasa, Iranshahr, Kermanshah, Khoramabad, Sarab, Shahr-e-kord, Yasuj, Zahedan and Zanjan. Each of these stations has the most optimal performance in their input and output values rather than other stations. The best values for total solar fraction, for example, belong to Bandar Abbas, Bandar-eLengeh, and Chabahar stations. And/or the best solar contribution to heating belongs to Sarab station with a value of $3,428 \mathrm{kWh}$, making this station to fall into the category of efficient stations. In the CCR model, 13 stations have also been chosen as efficient stations. The only difference is that Bandar-e-Lengeh station in the CCR model does not have an efficiency of $100 \%$ and, hence, Ghoochan and Birjand stations have been appointed as efficient stations.

Final comparisons and analyses of the BBC and CCR models reveal that the results obtained from the CCR model show lower efficiency in stations under study. The average efficiency of stations in the BBC and CCR models are respectively $93.7 \%$ and $92.4 \%$. However, the most efficient stations are identical in both models. Stations with an efficiency of lower than $100 \%$ should follow one of the efficient stations with similar geographical conditions and facilities to improve one or more input and output indices to enhance final efficiency.

\subsection{Economic analysis}

The results of the economic analysis performed for the 47 stations studied are given in Table 4 . The parameters to be evaluated are the cost per kWh of solar energy produced, the payback time, and the NPV. Based on the results, due to the negative NPV parameter in all stations, it can be seen that in all stations studied in Iran, in the current situation, the use of SWHs is not cost-effective. This can be due to the high cost of SWHs in Iran due to their immature technology, cheap fossil fuels, high inflation, and the lack of interest-free loans or subsidies for solar heating. The results show that the cheapest solar heating at $0.116 \$ / \mathrm{kWh}$ is at Sarab station and the most expensive solar heating at $0.302 \$ / \mathrm{kWh}$ is at Chabahar station. Also, according to the statistical analysis, the average price of home solar heating in Iran is $0.160 \$ / \mathrm{kWh}$. Regarding the NPV parameter, it should be noted that in all stations, this parameter is a negative value and the highest negative value with $\$ 3968$ is related to the Chabahar station. In the case of Chabahar station, which was able to meet $100 \%$ of its heat needs by SWHs, but has the highest negative NPV

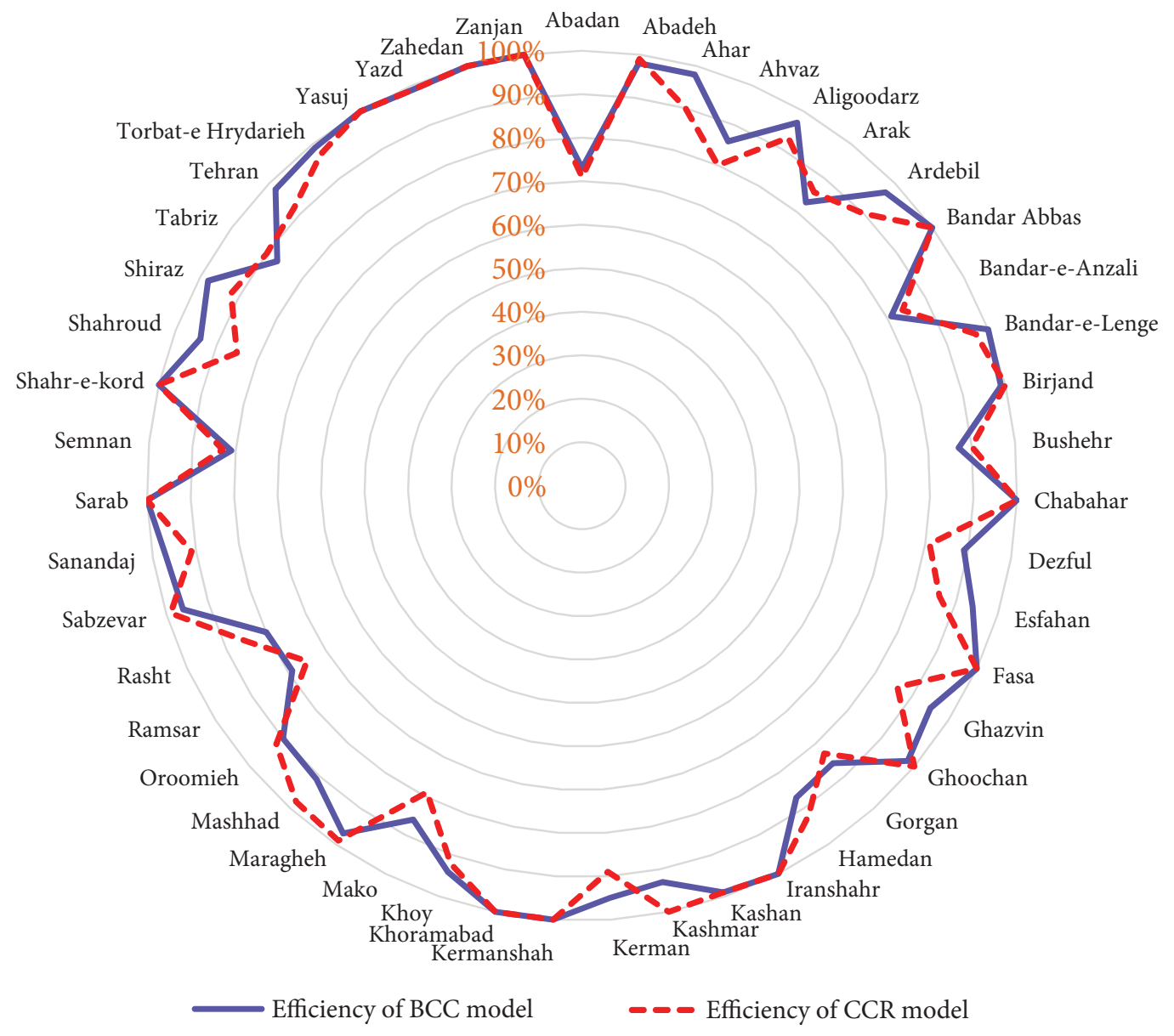

Figure 8. The results obtained from the BBC and CCR models 
Table 4. Results of economic analysis of the studied stations

\begin{tabular}{|c|c|c|c|c|c|}
\hline Station & $\begin{array}{c}\text { Cost of } \\
\text { energy }(\$ / \mathrm{kWh})\end{array}$ & NPV (\$) & Station & $\begin{array}{c}\text { Cost of } \\
\text { energy }(\$ / k W h)\end{array}$ & NPV (\$) \\
\hline Abadan & 0.225 & -3963 & Kermanshah & 0.132 & -3946 \\
\hline Abadeh & 0.129 & -3946 & Khoramabad & 0.135 & -3947 \\
\hline Ahar & 0.126 & -3945 & Khoy & 0.134 & -3947 \\
\hline Ahvaz & 0.231 & -3964 & Mako & 0.136 & -3949 \\
\hline Aligoodarz & 0.158 & -3955 & Maragheh & 0.132 & -3947 \\
\hline Arak & 0.142 & -3950 & Mashhad & 0.157 & -3953 \\
\hline Ardebil & 0.124 & -3945 & Oroomieh & 0.119 & -3942 \\
\hline Bandar Abbas & 0.253 & -3964 & Ramsar & 0.199 & -3962 \\
\hline Bandar-e-Anzali & 0.193 & -3961 & Rasht & 0.185 & -3959 \\
\hline Bandar-e-Lenge & 0.267 & -3965 & Sabzevar & 0.153 & -3952 \\
\hline Birjand & 0.123 & -3942 & Sanandaj & 0.130 & -3946 \\
\hline Bushehr & 0.255 & -3965 & Sarab & 0.116 & -3942 \\
\hline Chabahar & 0.302 & -3968 & Semnan & 0.146 & -3949 \\
\hline Dezful & 0.240 & -3965 & Shahr-e-kord & 0.123 & -3944 \\
\hline Esfahan & 0.137 & -3948 & Shahroud & 0.131 & -3946 \\
\hline Fasa & 0.134 & -3946 & Shiraz & 0.141 & -3949 \\
\hline Ghazvin & 0.134 & -3947 & Tabriz & 0.138 & -3949 \\
\hline Ghoochan & 0.131 & -3946 & Tehran & 0.155 & -3952 \\
\hline Gorgan & 0.162 & -3954 & Torbat-e Hrydarieh & 0.147 & -3951 \\
\hline Hamedan & 0.130 & -3947 & Yasuj & 0.138 & -3949 \\
\hline Iranshahr & 0.214 & -3961 & Yazd & 0.148 & -3950 \\
\hline Kashan & 0.150 & -3951 & Zahedan & 0.143 & -3948 \\
\hline Kashmar & 0.161 & -3953 & Zanjan & 0.120 & -3943 \\
\hline Kerman & 0.136 & -3947 & & & \\
\hline
\end{tabular}

and the highest cost per kWh of solar heat production, it should be noted that this station provides all the heat required by the SWHs due to Low heat demand and not high solar heat production. Therefore, Chabahar station has become the most economically unsuitable station.

\section{Conclusions}

Despite the high solar potential and adequate sunny hours, affordable solar collectors are not yet widely welcomed in Iran. The potential for the application of household SWH needs to be determined in detail due to a need for saving fossil fuels, not complicated technology of solar collectors and to diminish the rate of environmental pollution. Given the importance of the above discussions, the environmental-technical analysis of SWH applications in 47 Iranian stations was carried out using climatic data of METEONORM as input to TSOL software. Finding the potential of solar heating of stations located in different climates of Iran, the technical-economic-environmental study of heat supply required by the domestic sector, and ranking of various stations in order to find the most suitable and unsuitable stations, are among the innovations of the present work. The DEA-BCC and DEA-CCR models were then used in GAMS (v. 24.1) to rank stations.
The main results of this study are as follow:

- Chabahar station can supply $100 \%$ of its demand by the SWH;

- Bandar-e-Anzali and Ramsar stations have the worst condition in terms of required heat supplied by $\mathrm{SWH}$;

- In Bandar Abbas and Iranshahr stations, 100\% of SHW demand have generated by SWH;

- The average supply of total thermal energy, the energy required to space heating and the energy required for SHW by SWH in all stations are respectively $40.8 \%$, $2252.3 \mathrm{kWh}(25.2 \%)$, and 2707.4 (96.2\%);

- In stations under study, a total of $64.5 \mathrm{t} \mathrm{CO}_{2}$ is prevented from emission annually by using $\mathrm{SWH}$;

- Major need for an auxiliary gas boiler is for space heating;

- The CCR and BBC models introduced Bandar Abbas, Chabahar, Fasa, Iranshahr, Kermanshah, Khoramabad, Sarab, Shahr-e-kord, Yasuj, Zahedan and Zanjan stations jointly as best stations in Iran in terms of using SWHs;

- The CCR and BBC models introduced Abadan and Rasht stations as the most inefficient stations in Iran;

- The BBC model estimates efficiency of using SWH more than the CCR model;

- The cheapest solar heating is $0.116 \$ / \mathrm{kWh}$; 
- In all stations studied in Iran, the use of SWHs is not cost-effective.

The present work is not only the use of TSOL software but by writing a code in GAMS software two different models of DEA method have also been used to rank the stations located in Iran. Apart from the fact that the results of the present work are practical for Iran and can be a roadmap for energy decision-makers, especially solar heating in Iran, these results can be generalized to other parts of the world with similar climatic conditions. Also, the present work and the method of data analysis and ranking can be easily done anywhere in the world.

\section{Acknowledgements}

This research was supported by Prince of Songkla University, Thailand from the grant number ENV6402012N.

\section{References}

Cooper, W. W., Seiford, L. M., \& Zhu, J. (2011). Data envelopment analysis: History, models, and interpretations. In Handbook on data envelopment analysis (pp. 1-39). Springer. https://doi.org/10.1007/978-1-4419-6151-8_1

Du, K., Calautit, J., Wang, Z., Wu, Y., \& Liu, H. (2018). A review of the applications of phase change materials in cooling, heating and power generation in different temperature ranges. Applied Energy, 220, 242-273. https://doi.org/10.1016/j.apenergy.2018.03.005

Gautam, A., Chamoli, S., Kumar, A., \& Singh, S. (2017). A review on technical improvements, economic feasibility and world scenario of solar water heating system. Renewable and Sustainable Energy Reviews, 68, 541-562.

https://doi.org/10.1016/j.rser.2016.09.104

International Energy Agency. (2015). Energy and climate change (World energy outlook special report). OECD/IEA.

International Energy Agency. (2017). World energy outlook, 2017 (report). IEA, OECD.

Iranmanesh, S., Ong, H. C., Ang, B. C., Sadeghinezhad, E., Esmaeilzadeh, A., \& Mehrali, M. (2017). Thermal performance enhancement of an evacuated tube solar collector using graphene nanoplatelets nanofluid. Journal of Cleaner Production, 162, 121-129. https://doi.org/10.1016/j.jclepro.2017.05.175

Jahangiri, M., Alidadi Shamsabadi, A., \& Saghaei, H. (2018). Comprehensive evaluation of using solar water heater on a household scale in Canada. Journal of Renewable Energy and Environment, 5(1), 35-42.

Jamar, A., Majid, Z. A. A., Azmi, W. H., Norhafana, M., \& Razak, A. A. (2016). A review of water heating system for solar energy applications. International Communications in Heat and Mass Transfer, 76, 178-187.

https://doi.org/10.1016/j.icheatmasstransfer.2016.05.028

Khan, M. M. A., Ibrahim, N. I., Mahbubul, I. M., Ali, H. M., Saidur, R., \& Al-Sulaiman, F. A. (2018). Evaluation of solar collector designs with integrated latent heat thermal energy storage: A review. Solar Energy, 166, 334-350. https://doi.org/10.1016/j.solener.2018.03.014

Liu, J., Ding, F. Y., \& Lall, V. (2000). Using data envelopment analysis to compare suppliers for supplier selection and performance improvement. Supply Chain Management: An International Journal, 5(3), 143-150.

https://doi.org/10.1108/13598540010338893
Mahbubul, I. M., Khan, M. M. A., Ibrahim, N. I., Ali, H. M., AlSulaiman, F. A., \& Saidur, R. J. R. E. (2018). Carbon nanotube nanofluid in enhancing the efficiency of evacuated tube solar collector. Renewable Energy, 121, 36-44.

https://doi.org/10.1016/j.renene.2018.01.006

Mamouri, S. J., \& Bénard, A. (2018). New design approach and implementation of solar water heaters: A case study in Michigan. Solar Energy, 162, 165-177.

https://doi.org/10.1016/j.solener.2018.01.028

Marefati, M., Mehrpooya, M., \& Shafii, M. B. (2018). Optical and thermal analysis of a parabolic trough solar collector for production of thermal energy in different climates in Iran with comparison between the conventional nanofluids. Journal of Cleaner Production, 175, 294-313.

https://doi.org/10.1016/j.jclepro.2017.12.080

Modi, A., Bühler, F., Andreasen, J. G., \& Haglind, F. (2017). A review of solar energy based heat and power generation systems. Renewable and Sustainable Energy Reviews, 67, 10471064. https://doi.org/10.1016/j.rser.2016.09.075

Mohammadi, K., Mostafaeipour, A., Dinpashoh, Y., \& Poura, N. (2014). Electricity generation and energy cost estimation of large-scale wind turbines in Jarandagh, Iran. Journal of Energy, 2014, 613681. https://doi.org/10.1155/2014/613681

Mohammadi, S. M., Mortezapour, H., \& Jafari, N. K. (2017). Numerical analysis of using hybrid photovoltaic-thermal solar water heater in Iran. Journal of Agricultural Machinery, 7, 221-233.

Mollahosseini, A., Hosseini, S. A., Jabbari, M., Figoli, A., \& Rahimpour, A. (2017). Renewable energy management and market in Iran: A holistic review on current state and future demands. Renewable and Sustainable Energy Reviews, 80, 774-788. https://doi.org/10.1016/j.rser.2017.05.236

Mostafaeipour, A., \& Abesi, S. (2010, March 7-13). Wind turbine productivity and development in Iran. In 2010 International Conference on Biosciences, Cancun, Mexico.

https://doi.org/10.1109/BioSciencesWorld.2010.30

Mostafaeipour, A., Zarezade, M., Goudarzi, H., Rezaei-Shouroki, M., \& Qolipour, M. (2017). Investigating the factors on using the solar water heaters for dry arid regions: A case study. Renewable and Sustainable Energy Reviews, 78, 157-166. https://doi.org/10.1016/j.rser.2017.04.102

Our World in Data. (n.d.). BP statistical; Review of Global Energy 2020, Cumulative installed solar capacity, measured in gigawatts (GW). Retrieved April 13, 2021, from https://ourworldindata.org/grapher/installed-solar-pv-capacity

Pahlavan, S., Jahangiri, M., Alidadi Shamsabadi, A., \& Khechekhouche, A. (2018). Feasibility study of solar water heaters in Algeria, a review. Journal of Solar Energy Research, 3(2), 135-146.

Pandey, K. M., \& Chaurasiya, R. (2017). A review on analysis and development of solar flat plate collector. Renewable and Sustainable Energy Reviews, 67, 641-650. https://doi.org/10.1016/j.rser.2016.09.078

Sardouei, M. M., Mortezapour, H., \& Naeimi, K. J. (2018). Temperature distribution and efficiency assessment of different PVT water collector designs. Sādhanā, 43(6), 84. https://doi.org/10.1007/s12046-018-0826-x

Shahsavari, A., Yazdi, F. T., \& Yazdi, H. T. (2019). Potential of solar energy in Iran for carbon dioxide mitigation. International Journal of Environmental Science and Technology, 16(1), 507-524. https://doi.org/10.1007/s13762-018-1779-7

Solar resource maps of Iran. (2020). Global Horizontal Irradiation map. Solargis. Retrieved February 08, 2020, from https:// solargis.com/maps-and-gis-data/download/iran 
Teamah, H. M., Lightstone, M. F., \& Cotton, J. S. (2018). Potential of cascaded phase change materials in enhancing the performance of solar domestic hot water systems. Solar Energy, 159, 519-530. https://doi.org/10.1016/j.solener.2017.11.034

Uctug, F. G., \& Azapagic, A. (2018). Life cycle environmental impacts of domestic solar water heaters in Turkey: The effect of different climatic regions. Science of the Total Environment, $622,1202-1216$.

https://doi.org/10.1016/j.scitotenv.2017.12.057

Varghese, J., \& Manjunath, K. (2017). A parametric study of a concentrating integral storage solar water heater for domestic uses. Applied Thermal Engineering, 111, 734-744.

https://doi.org/10.1016/j.applthermaleng.2016.09.127
Yousef Nezhad, M. E., \& Hoseinzadeh, S. (2017). Mathematical modelling and simulation of a solar water heater for an aviculture unit using MATLAB/SIMULINK. Journal of Renewable and Sustainable Energy 9(6), 063702. https://doi.org/10.1063/1.5010828

Zarezade, M., \& Mostafaeipour, A. (2016). Identifying the effective factors on implementing the solar dryers for Yazd province, Iran. Renewable and Sustainable Energy Reviews, 57, 765-775. https://doi.org/10.1016/j.rser.2015.12.060

Zhou, D., \& Zhao, C. Y. (2011). Experimental investigations on heat transfer in phase change materials (PCMs) embedded in porous materials. Applied Thermal Engineering, 31(5), 970977. https://doi.org/10.1016/j.applthermaleng.2010.11.022

\section{APPENDIX}

\begin{tabular}{|c|c|c|c|}
\hline \multicolumn{4}{|c|}{ Nomenclature } \\
\hline$I$ & Total hourly radiation on a horizontal surface $\left(\mathrm{kJ} / \mathrm{m}^{2}\right)$ & $T_{A}$ & Air temperature $(\mathrm{K})$ \\
\hline$\rho$ & Collector energy balance (kW) & $T_{k m}$ & Average temperature of collector $(\mathrm{K})$ \\
\hline$C$ & Cost of the SWH system (\$) & $k_{q}$ & Quadratic heat transfer coefficient $\left(\mathrm{W} / \mathrm{m}^{2} \cdot \mathrm{k}^{2}\right)$ \\
\hline$e$ & Useful life (year) & $Q_{C L ; D H W}$ & Collector loop heating for DHW (kW) \\
\hline$n$ & Number of years $(-)$ & $Q_{S, H L}$ & Solar heating for heating load $(\mathrm{kW})$ \\
\hline$d$ & Rate of decline (\%) & $Q_{A u x, D H W}$ & Auxiliary heating for DHW (kW) \\
\hline$N P V$ & Net present value $(\$)$ & $Q_{A u x, H H L}$ & Auxiliary heating for heating load $(\mathrm{kW})$ \\
\hline$\alpha$ & Tilt angle $\left(^{\circ}\right)$ & $k_{t}$ & Hourly clearness index $(-)$ \\
\hline$H L$ & Heating load $(\mathrm{kW})$ & $I_{d}$ & Hourly diffuse radiation on a horizontal surface $\left(\mathrm{kJ} / \mathrm{m}^{2}\right)$ \\
\hline DEA & Data envelopment analysis (-) & $G_{d i r}$ & Part of solar radiation striking a tilted surface $(\mathrm{kW})$ \\
\hline$D M U$ & Decision making unit $(-)$ & $\eta_{0}$ & Collector's zero-loss efficiency (\%) \\
\hline TSOL & Thermal solar $(-)$ & $f_{\text {IAM }}$ & Incidence angle modifier factor $(-)$ \\
\hline RESs & Renewable energy sources $(-)$ & $G_{\text {diff }}$ & Diffuse solar radiation striking a tilted surface $(\mathrm{kW})$ \\
\hline$B C C$ & Model name (-) & $f_{I A M, \text { diff }}$ & Diffuse incidence angle modifier factor $(-)$ \\
\hline CCR & Model name (-) & $k_{0}$ & Simple heat transfer coefficient $\left(\mathrm{W} / \mathrm{m}^{2} \cdot \mathrm{k}\right)$ \\
\hline DHW & Domestic hot water $(-)$ & $C_{0}$ & Total purchase cost $(\$)$ \\
\hline SHW & Sanitary hot water $(-)$ & $C_{O \& M}$ & Total annual operating and maintenance costs (\$) \\
\hline SWH & Solar water heater $(-)$ & $Q_{u}$ & Useful energy collected by the solar collectors $(\mathrm{kW})$ \\
\hline$R_{t}$ & Total revenue $(\$)$ & $\eta_{h}$ & Efficiency of the auxiliary boiler (\%) \\
\hline
\end{tabular}

